Uitto, M., Lutovac, S., Jokikokko, K. \& Kaasila, R. 2018. Recalling life-changing teachers: positive memories of teacher-student relationships and the emotions involved. International Journal of Educational Research 87, 47-56. http://dx.doi.org/10.1016/j.ijer.2017.11.004

\title{
Recalling Life-Changing Teachers: Positive Memories of Teacher-Student Relationships and the Emotions Involved
}

\author{
Minna Uitto, Sonja Lutovac, Katri Jokikokko and Raimo Kaasila \\ Faculty of Education, University of Oulu
}

Minna Uitto, Faculty of Education, University of Oulu, P.O. Box 2000, FI-90014 University of Oulu, Finland, email: minna.uitto@ oulu.fi; Sonja Lutovac, Faculty of Education, University of Oulu, P.O. Box 2000, FI-90014 University of Oulu, Finland, email: sonja.lutovac@ oulu.fi; Katri Jokikokko, Faculty of Education, University of Oulu, P.O. Box 2000, FI-90014 University of Oulu, Finland, email: katri.jokikokko@ oulu.fi; Raimo Kaasila, Faculty of Education, University of Oulu, P.O. Box 2000, FI-90014 University of Oulu, Finland, email: raimo.kaasila@ oulu.fi

Correspondence concerning this article should be addressed to Minna Uitto, Faculty of Education, University of Oulu, P.O. Box 2000, FI-90014 University of Oulu, Finland. Phone +358 29448 3728, Email: minna.uitto@oulu.fi 
Abstract

Little empirical research has been done about teacher-student relationships and the emotions involved from the students' perspective. Our research employs narrative approach and addresses such memories of teachers that former students described as having very positive, even lifechanging significance for them. We ask what do positive memories of teachers tell us about teacher-student relationships and the emotions involved. The findings illustrate how teachers establish emotional bonds with their students as well as their sensitivity towards the students' lifecircumstances and emotions. In addition, teachers' socio-emotional involvement in students' lives is reflected in students' emotions. For teacher education, we argue the need to implement the understanding of the meaning of emotions in teacher-student relationships.

Keywords: emotions; narrativity; teacher memories; teacher-student relationships 


\author{
Recalling Life-Changing Teachers: \\ Positive Memories of Teacher-Student Relationships and the Emotions Involved
}

\title{
1. Introduction
}

Emotions and their significance for teachers' work have too rarely been fully taken into account in educational research (Boler, 1999; Hargreaves, 2000; Nias, 1996; O’Connor, 2008; Zembylas, 2007). However, the situation has rapidly changed during the last decade (Uitto, Jokikokko, \& Estola, 2015; see also Fried, Mansfield, \& Dobozy, 2015). The significant role of emotions has been recognised in the various relationships related to teachers' work, for example in teachers' relationships with students (Newberry, 2010) and students' parents (Lasky, 2000). Also, the meaning of emotions for teachers' professional identity and professional learning (e.g. Day \& Leitch, 2001; O’Connor, 2008; Shapiro, 2010; Zembylas, 2003), and in the case of educational changes and reforms (e.g. Hargreaves, 2005; Kelchtermans, 2005) has been illustrated. In addition, emotional exhaustion among teachers (e.g. Chan, 2009; Skaalvik \& Skaalvik, 2009), their emotional intelligence (e.g. Corcoran \& Tormey, 2012) as well as regulation of emotions (e.g. Hosotani \& Imai-Matsumura, 2011) have been studied. Furthermore, it has been pointed out that teachers' emotions affect students' emotions (e.g. Becker et al., 2014) and that emotions play an important role in students' learning (e.g. Morcom, 2014).

Prior research on former students' memories of school and their teachers has paid attention to the meaning of teacher-student relationships for former students (e.g. Uitto, 2012). However, prior research has infrequently taken into account the aspect of emotions (exceptions include: Southgate, 2003; Uitto \& Estola, 2009) in these relationships. There are some studies with a focus on students' positive and negative memories of their teachers (e.g. Chang-Kredl \& 


\section{TEACHER-STUDENT RELATIONSHIPS AND THE EMOTIONS INVOLVED}

Colannino, 2017). However, prior research has often highlighted students' negative memories of their teachers, especially related to inequality, domination, punishment, favouritism, humiliation, subordination and misuse of authority (e.g. DePalma, Membiela, \& Suárez, 2011; Luttrell, 1993; Mitchell \& Weber, 1999; Salo, 2005). Special attention in research has been paid to memories that in-service and pre-service teachers have about school and teachers (e.g. Chang-Kredl \& Kingsley, 2014; DePalma et al., 2011; Kaasila, 2007; Lutovac \& Kaasila, 2014; Mitchell \& Weber, 1999; Paul \& Smith, 2000). These studies have emphasised, for example, the significance of one's own teachers for becoming a teacher oneself (e.g. Flores \& Day, 2006).

In this article, we address the following gap in research. First, there is little research on the emotions in teacher-student relationships, especially from the viewpoint of former students. Thus, we here focus on former students' memories of their teachers to explore what the memories reveal about teacher-student relationships and the emotions involved. Second, the research in terms of teacher memories has focused on the meaning of negative school time memories for students. Also the research material used in this article has already been studied from the viewpoint of negative memories (Uitto, 2011). Therefore, we here focus namely on such memories of teachers that former students described as having very positive, even life-changing significance for them. Our research question is: what do positive memories of teachers tell us about teacher-student relationships and the emotions involved?

\section{Theoretical framework}

We approach teachers' work as being relational by nature (e.g. Aultman, WilliamsJohnson, \& Schutz, 2009; Hansen, 1998; Kelchtermans, 2009; van Manen, 1991). Teachers are in relationships with their colleagues, principals and students' parents, for example, but the 


\section{TEACHER-STUDENT RELATIONSHIPS AND THE EMOTIONS INVOLVED}

most significant relationships in their work are naturally the ones that they have with their students. Those student relationships are essential in making teaching possible (e.g. Kelchtermans, 2009; van Manen, 1991). The significance of teacher-student relationships for students' learning outcomes (Newberry, 2010; Newberry \& Davis, 2008) and for the well-being of teachers and students at school (Soini, Pyhältö, \& Pietarinen, 2010) has been acknowledged. Studies on students' experiences have also brought up the meaning of teacher-student relationships and how students value teachers who appreciate them and show them individual consideration and sympathy (Raufelder et al., 2016).

Van Manen $(1991 ; 1994 ; 2002)$, among others, talks about the pedagogical relationship and its intentional nature: teachers care for their students as they are now and as they may become (van Manen, 1991). Teacher-student relationships are personal relationships embracing each student's individuality (e.g. van Manen \& Li, 2002), but yet they always form in the midst of other relationships. For example, teachers are at the same time in relationships not just with individual students, but a group of students (van Manen, 1991).

When discussing the relational nature of teachers' work in this article, two other concepts by van Manen (1991) are also relevant: pedagogical moments and pedagogical tact. Van Manen defines pedagogical moments as active encounters, i.e. the situations that require teachers' action or inaction. Pedagogical tact, for van Manen, manifests itself in as openness to children's experiences, as being attuned to subjectivity, as a subtle influence, as situational confidence, as an improvisational gift and sometimes also as holding back from doing something.

Since teachers' work is relational, it is inseparably emotional (e.g. Hargreaves, 2000; 2001; Nias, 1996). Hargreaves (1998; 2000) even conceptualises teachers” work as “an emotional practice" (see also Mayer, 2009). We understand emotions not only as personal and private experiences, but as constructed in social interaction (Zembylas, 2007). Social 


\section{TEACHER-STUDENT RELATIONSHIPS AND THE EMOTIONS INVOLVED}

interaction is here understood in the form of teacher-student relationships; however, as mentioned earlier, these relationships are constructed amid other relationships in educational and institutional settings. Being a teacher is then a matter of socio-emotional involvement in teaching; it requires teachers' emotional involvement with students and this involvement is then reflected in students' emotions, too. Since relationships between teachers and students are emotional, those relationships guide the decisions that teachers make as well as their ways of teaching and organising the teaching (Hargreaves, 1998).

There is a vast amount of research on teacher-student relationships (e.g. van Manen, 1991), but rarely has this research raised up the meaning of emotions in these relationships. It is notable that prior research on emotions in teacher-student relationships has focused rather on teacher perspective instead of students. Prior research has illustrated the significance of emotions in how teachers build and foster teacher-student relationships (Newberry, 2010; Yan, Evans, \& Harvey, 2011). In addition, research has paid attention to teachers' perceptions or conceptions about the emotions involved in teacher-student relationships (Hargreaves, 2000; Newberry \& Davis, 2008). Furthermore, teachers have described their need for close relationships with students and the strong feelings of emotional warmth towards them (Cowie, 2011). Emotions and their involvement in teacher-student relationships have also been studied via themes such as closeness (Newberry \& Davis, 2008), gratitude (Howells, 2014), emotional labour of caring (Isenbarger \& Zembylas, 2006), teachers' professional identity (den Brok, van der Want, Beijaard, \& Wubbels, 2013), ethical boundaries (Aultman et al., 2009) and teacher emotions within the particular social and cultural context (Zembylas, 2004). Prior research on emotions in teacher-student relationships has also brought understanding to how school structures, pedagogy and curriculum planning affect the formation of these relationships (Hargreaves, 1998). 
Emotions have long had a marginal role in educational research, which has consequences, also for teacher education: previous studies have discussed the long-lasting image among teachers that they should be rational professionals who are able to manage their own emotions and control their students' emotional expressions (Boler, 1999; Schutz \& Zembylas, 2009; Uitto et al., 2015). Although nowadays many researchers seem to agree that emotions in teachers' work should be dealt with more profoundly in teacher education, methods of achieving that have been discussed less (Uitto et al., 2015). Supporting the social and emotional development of future teachers is crucial. For teacher education, we will argue the need to implement the understanding of the meaning of emotions in teachers' work and especially in teacher-student relationships.

\section{Methodology}

We employ a narrative approach. Arguably, it is only through storytelling that we can get hold of people's memories (Carter, 1993). We see memories as reconstructions, situated in context and the result of storytelling and retellings (Elbaz-Luwisch, 2005; Riessman, 2008). This means that in the process of remembering, people move between the past, present and future. Hence, memories not only reflect the past, but also the current society. Holstein and Gubrium (2000) argue for the benefits of narrative approach in studying emotions: As storytelling is based on experiences, the memories work as mediating tools in which emotions become contextualised in a broader social, cultural, and political context (Riessman, 2008). Storytelling makes it possible to address the nuances of emotions related to the memories of teachers (Carter, 1993). Furthermore, research has offered many explanations concerning what things are remembered and why. Emotions have been considered to play a significant role in 
recollections, and it has been suggested that emotional events are better remembered (Crawford et al., 1992; Southgate, 2003).

\subsection{The collection of the research material}

In September 2006, the Finnish magazine Yhteishyvä $\ddot{a}^{1}$ published the first author's request ${ }^{2}$ for people to write about their teachers and to submit that writing as material for research. In total, 141 letters and emails of various lengths were received from 116 women and 25 men. The writers represent a diverse portrait of Finnish society as they had varied educational and occupational backgrounds. All the writers attended Finnish schools in both rural and urban settings, but at different times. Nearly half of the writers were over 60 years of age; however, the writers ranged by age from 16 to 87 years. The writers often recalled teachers they had as children or young adults. This meant that the memories mostly surround basic education and upper secondary school, when the writers were approximately seven to eighteen years of age. However, there were also some memories of vocational education, adult education, and higher education. Since, the writers volunteered to participate in the research based on a short request in a magazine, inevitably, they had something to say.

\footnotetext{
${ }^{1}$ Yhteishyvä magazine is aimed broadly at both women and men of different ages. It is a free magazine delivered to the members of the S Group cooperative, which runs several chains of stores in Finland. In 2006, the magazine had a circulation of 1,340,000 (Yhteishyvä 9/2006, p. 131).

2 "Do you remember your teacher? [...] Do you want to participate in the research by writing memories about your own teachers? The form of the story is free, as well as the length. Every memory is valuable. The writings will be treated with absolute confidentiality. Memories or parts of them can be published in research reports [...] Attach to your writing information about your age, gender, educational background, and your contact information."
} 


\section{TEACHER-STUDENT RELATIONSHIPS AND THE EMOTIONS INVOLVED}

\subsection{The analysis of the research material}

The analysis of the research material proceeded in the following way: Firstly, the first author provided a summary of the content of each of the 141 writings in a table. Since we focus here on such teacher memories that the writers reported as having very positive, even life-changing significance for them, we eliminated all the research material that did not comply with the focus. This narrowed the research material down to 23 writings. Three of the 23 writers were men, and 20 women $^{3}$. They worked at the time of the writing for example in the fields of education, caring industry, business, research, agriculture and catering business or had retired. Not all writers mentioned the occupation. The writers wrote about their teachers in different ways: some recalled one particular teacher, whereas some recalled many teachers. Then again, some focused on telling many memories of a teacher, whereas some chose to tell only one particular memory.

Secondly, we proceeded with the thematic analysis of the positive memories in the 23 writings. Since both teachers and students were present in the memories, the analysis focused on teacher-student relationships (see Uitto, 2012). We first analysed the memories independently searching for similarities and differences, and then formed themes in a joint discussion. In case of slightly different interpretations about the themes, we negotiated the different views. We also paid attention to what the writers were telling about their teachers and the whole context of the memories (Riessman, 2008), the way the memories were told and the meaning-making processes. Based on this analysis, we established four themes related to teacher-student relationships: a) a teacher helped students to progress along their educational paths; b) a teacher provided love and understanding to students; c) a teacher gave students advice on life, was a lifelong inspirer or a

\footnotetext{
${ }^{3}$ There were two writers in their twenties, three in their late thirties and two in their forties at the time of the writing. Five writers were between 50-59 years and five writers between 60-69 years. Two writers were in their mid-70s and two writers over 80 years of age. Two writers did not mention their age, but based on the writings they were older generation.
} 


\section{TEACHER-STUDENT RELATIONSHIPS AND THE EMOTIONS INVOLVED}

friend; and d) a teacher provided students insights, experiences or meaningful events. These themes are partially overlapping; a particular memory was situated under a particular theme depending on the main focus of the memory content.

Thirdly, we paid attention to how emotions play a significant role in the memories of teacherstudent relationships. Therefore, we applied holistic content analysis (Lieblich, Tuval-Mashiach, \& Zilber, 1998) in analysing the emotions. In analysing the memories of teacher-student relationships from the viewpoint of emotions, we noticed that some writers named emotions explicitly as describing their own emotions or how their teachers' emotions appeared. However, sometimes emotions were present in the memories implicitly: the memory could have an overall emotional tone or way of telling, which is not surprising, since prior research has demonstrated the significance of emotions for what is remembered (e.g. Southgate, 2003).

\section{Findings}

Here, we provide four memory examples of each theme related to teacher-student relationships: a) a teacher helped students to progress along their educational paths; b) a teacher provided love and understanding to students; c) a teacher gave students advice on life, was a lifelong inspirer or a friend; and d) a teacher provided students insights, experiences or meaningful events. The four memories - selected because they were rich and detailed -are introduced in length in order to be fully able to illustrate teacher-student relationships and the emotions involved. For ethical reasons to ensure the writers' anonymity, we changed their names, as well as all names of places and other people appearing in the memories.

\subsection{A teacher helped students to progress along their educational paths}




\section{TEACHER-STUDENT RELATIONSHIPS AND THE EMOTIONS INVOLVED}

Based on the memories, teachers were described to have life-changing meaning for students in a very concrete way - there were memories that illustrated how teachers influenced students' educational paths, for example by helping the students to apply to higher levels of education, ${ }^{4}$ These teachers were also described in their student relationships as being sensitive to students' backgrounds and abilities. The following memory illustrates these aspects in teacher-student relationships and the emotions involved. One of the several teachers that Tuula, in her seventies, recalls, was a female teacher in elementary school:

The year changed. In spring term 1949, Martta Keskitalo became more and more interested in my success at school. She wanted to know if I had the possibility to apply to a grammar school. I had to ask my parents about it. I had been bringing good school reports home. My father looked thoughtful. I think that it was not only my situation that affected his decision. Other things, which were unpleasant from my father's point of view, supported my situation as well. Father had started to regret our moving from [place] to [place] ... Father sold our farm and purchased a smaller plot of land in [place]. I realised that he had also been thinking about me when he chose the location: there was a grammar school in [the area where the farm was located]! I told my teacher that now I could apply to this school. The move to [place] would take place at the end of May, just before my entrance exam. Martta Keskitalo took this as a challenge. She swore to me that her best student from this school in the middle of nowhere would pass the exam! We started to work together. I often went to her apartment after school to do exercises. Every Sunday afternoon in May I spent with her, cramming hard [for the exam]. When school ended, the average grade on my certificate was 8.8 .

\footnotetext{
${ }^{4}$ There used to be a parallel school system in Finland. This meant that all children went to elementary school (began at the age of seven), but usually at the age of 11, educational routes became differentiated. Some pupils went to grammar schools after entrance exams (going to grammar school opened up a possibility to upper secondary school also) and other pupils continued their studies in elementary schools. The comprehensive school was established in the 1970's, which meant that all children attend 9 years of comprehensive school (grades 1-6 in primary school and grades 7-9 in lower secondary school), after which students usually apply to vocational education or to upper secondary school. (see Simola, Heikkinen, \& Silvonen, 1998; Tuomaala, 2004.)
} 


\section{TEACHER-STUDENT RELATIONSHIPS AND THE EMOTIONS INVOLVED}

Our removal van was late. It came at midnight. However, I got to school on time. My father waited in the city centre until the exam was finished. The prize that I gave him, together with my teacher Martta Keskitalo, brought tears to his eyes: I was accepted for the first grade of the school with the best score! My father was moved and said, "Well, we will have to make you the next Hertta Kuusinen" ${ }^{5 " . ~ I ~}$ immediately wrote my thanks to my teacher. I got a reply from her that ended with an aphorism: "Always turn your face towards the light, so that the shadows fall behind you." (Letter 51)

The memory demonstrates the significance of the particular teacher for Tuula as she related her life circumstances when she was a pupil and how these affected her schooling path. The memory brings up how the teacher not only encouraged her student to think about enrolling in a grammar school but also how she supported her student's studies for the entrance exam. Tuula describes explicitly her father's emotions (regret and being moved) and also her teacher's growing interest towards Tuula's studies. Emotions are also implicitly present in her way of telling: the teacher-student relationship comes across in the memory as one-on-one relationship characterised by intimacy and closeness (see Newberry \& Davis, 2008), and in which the teacher and the student worked together to achieve the goal. In addition, emotions are implicitly present as the teacher is described to have devoted her personal time to tutoring the student and hence, the relationship extends in this memory beyond the working hours and school context (Uitto, 2012; van Manen \& $\mathrm{Li}, 2002)$. The meaning of this relationship for the student shows in how Tuula reports her teacher's actual words: the teacher believed in her student and appeared to be very proud of her success.

The memory illustrates how emotions in teacher-student relationships form not only between the teacher and the student but in the midst of relationships (see Hargreaves, 2000; Zembylas, 2007). Here, the relationships to Tuula's family are present as the father especially is depicted to have a lot of significance for Tuula to be able to apply for grammar school. In addition, the memory reveals how the teacher took into account the student's home situation, which demonstrates the teacher's pedagogical tact towards the student (van Manen, 1991). The last episode in the memory

\footnotetext{
${ }^{5}$ A politician, who in the 1940s became only the second Finnish female minister ever.
} 


\section{TEACHER-STUDENT RELATIONSHIPS AND THE EMOTIONS INVOLVED}

further reveals the influence that teachers can have on their students' educational paths. Tuula's father's comparison of his daughter's success to that of Hertta Kuusinen, a historically important Finnish figure, demonstrates that such success and possibilities were seldom available to all people in those times, let alone those living in remote villages. The memory brings up the significance of the teacher for this particular student at the school time, but also still at the time of the writing.

\section{2. $\quad$ A teacher providing love and understanding to students}

Some of the memories focused on describing teachers as providing love to their students and showing understanding, support, encouragement or comfort towards them, or teachers were described as acting like parents. The following memory illustrates these aspects in teacher-student relationships and the emotions involved. Hanna, a female writer in her fifties, recalled in her writing only this one teacher, who taught her in the grammar school:

I can still remember how intensively I stared at the pile of material on the teacher's arm when she came to class at the beginning of a Finnish lesson. Was it a pile of exams, essays or - the best option - a book to read? The teacher acquainted us with [many Finnish and foreign authors]. She read many phenomenal books out loud in her clear and vivid voice ... She was the principal, she taught history and social studies, and she arranged student counselling. Her way of teaching was precise and consistent. She was able to keep discipline in the classroom without raising her voice or punishing people. She had authority and the ability to make sure there was peace to work.

Back then, I was amazed that she knew about the things that were going on in the classroom without anyone telling her. I was bullied throughout my time at grammar school. The teacher knew it. She couldn't get rid of it in the school, but she supported and encouraged me in going to school. I wasn't given good grades out of pity ... I think I definitely got sympathy in essay writing and, for example, in the grades for written presentations. But I didn’t always get As, although I was good at writing essays. The way this teacher taught history and social studies opened up to me so that I still like those subjects. 


\section{TEACHER-STUDENT RELATIONSHIPS AND THE EMOTIONS INVOLVED}

The teacher knew about my dismal home conditions and discreetly showed that to me ... Later studies and then work have opened my eyes. My mother must have had a difficult personality disorder, or else she wouldn't have oppressed first me and later a few of my siblings in the way she did. My congenital disorder was the object of constant ridicule, insults and guilt from my mother. I was bullied at school for the same reason. These days I often wonder how I maintained my mental health through the 17 years of torment. That wise and understanding teacher was an important support, although I did get along with all of my teachers. I loved going to school, learning, reading new books and the world that opened up through them ...

The teacher still knows about me and my [the exact number of] siblings, although she has retired and moved away from my home area. She knows because of me, as we are still in contact. I get postcards from different places and of course on my special days and before Christmas. Last spring, I visited them. That teacher told me now, decades later, that she and her husband, who was also a teacher, had wanted to adopt me. It didn’t work out back then ... Of course when I heard about their intentions, I got emotional, and all three of us cried. I can only imagine what being adopted would have made possible. Well, because of my current work, I know that a child's personality is constructed and supported even if just one adult shows acceptance, understanding and love. Even last spring, when I asked that teacher why she had remembered me all these decades, she answered: "Well, because we love you so much!" (Letter 47)

In the above memory the teacher-student relationship is first described via the teacher's authority and her ability to raise interest in the subject taught. Then Hanna tells very vividly about the teacher's support and encouragement as well as showing understanding towards the student's challenging home situation. The emotional tone in this memory is highly positive, as Hanna contrasts the negative emotions related to the difficult circumstances at home with the very positive, close and personal relationship with her teacher.

The memory is charged with emotions and Hanna describes explicitly her teacher's emotions (love) as well as her own emotions (amazement, love, guilt). The memory further demonstrates emotions in teacher-student relationships, apparent in how the memory illustrates the teacher's 


\section{TEACHER-STUDENT RELATIONSHIPS AND THE EMOTIONS INVOLVED}

emotions towards the student (e.g. Cowie, 2011). The latter is especially highlighted in how Hanna describes her teacher's attempts to adopt her during the school years and how Hanna cites her teacher's actual words about the love she felt towards Hanna. Furthermore, emotions in the relationship becomes demonstrated in the memory describing how the student felt towards her teacher. On one side, it shows Hanna's deep appreciation and gratitude for a particular teacher as a person and as a professional, and on the other, the memory shows the teacher's genuine care for the student, which, according to Hanna, stretched beyond school matters. Hanna recalls her difficult circumstances at home, how the teacher knew about them, and also how the teacher is still in touch with her reminding us of how teacher-student relationships and the emotions involved evolve outside school and school years (Hargreaves, 2000; Uitto, 2012). The teacher's sensitivity to Hanna's difficult home situation demonstrates what has been noted in the literature as the teacher's pedagogical tact in noticing the student's vulnerability, trying to support her in the best possible way and doing this in a discreet manner (as Hanna explains) (see van Manen, 1991).

This memory reminds us of Hargreaves (1998; 2000), who conceptualises teachers' work as an emotional practice. Hargreaves (1998) brings up how teachers value the emotional bonds they establish with their students as well as the purposes of educating the students as emotional, social and intellectual beings. Here, the memory emphasises the teacher's ability to create an emotional bond with the student. Furthermore, the value of being felt accepted and valuable as a person and as a student is highlighted in addition to learning and being inspired about the contents of teaching. However, what is notable also in this memory is that Hanna tells about the meaning of this particular teacher relationship not just as related to her school time but also to her later life.

The memory further illustrates emotions being formed in teacher-student relationships in the midst of other relationships (see Hargreaves, 2000; Zembylas, 2007). Hanna's family relationships, especially with her mother and siblings, are present in the memory as well as her relationships to the other students (Hanna tells that she was bullied at school). Hanna seems to be aware of the unique 


\section{TEACHER-STUDENT RELATIONSHIPS AND THE EMOTIONS INVOLVED}

nature of the kind of attention she received from the teacher; however, by elaborating on "I wasn't given good grades out of pity", she makes it very clear that despite the teacher's special attention, she was not given an easy ride when it came to school work.

\subsection{A teacher gave students advice on life, was a lifelong inspirer or a friend}

There were memories that described teachers giving students pedagogical insights or advice on life or practical issues. These teachers were depicted as inspiring students to take up a life-long hobby, go into a particular occupation, and become interested in learning or opening up a subject in a different way. Teachers could also be recalled as being students' friends even after school years, or being professional role models for their students later in life. The following memory illustrates these aspects in teacher-student relationships and the emotions involved. Liisa, a female writer in her late twenties, recalled three of her teachers:

\footnotetext{
The warmest memories that I have are of my biology teacher in lower secondary school. She ${ }^{6}$ was a rather strict teacher, which is why she was not particularly well-liked. In her lessons, I never felt that I was any better than the others. When I was finishing lower secondary school, this teacher invited me to have a personal appointment with her. I was worried, because usually personal appointments with teachers meant hearing some unpleasant comments about your behaviour. My teacher gave me an amazing talk. She told me that I was really gifted and that she could see that I would go far in my life. I was indeed interested in biology already before this talk, and I had considered studying biology or medicine [in the future]. However, this talk certainly inspired me and made me believe more in myself. I became a cell biologist who studies the brain. (Letter 33)
}

\footnotetext{
${ }^{6}$ The Finnish language has only one, gender-neutral personal pronoun (hän). Hence, it was not possible to determine based on the writing whether the teacher in question was a man or a woman. For the sake of readability, we use the pronoun "she" about the teacher.
} 


\section{TEACHER-STUDENT RELATIONSHIPS AND THE EMOTIONS INVOLVED}

In this memory Liisa focuses on telling about a particular pedagogical moment (van Manen, 1991) in the teacher-student relationship that had life-long significance for her. The teacher's “amazing talk" about Liisa's talent and potential inspired her to pursue career in biology. Emotions are explicitly present as Liisa describes her teacher as "well-liked" and her own emotions (not feeling any better, worry). Also the tone of the memory is emotional: Based on the memory, this particular pedagogical moment, further illustrating emotions involved in teacher-student relationships, was emotionally significant for Liisa, probably even more significant due to the fact that the teacher was described as being rather strict and not giving such positive feedback easily. The memory shows what kind of emotional significance a teacher's encouragement and feedback can have for a student.

Here, the viewpoint of emotions in teacher-student relationships forming in the midst of relationships is further accentuated (see Hargreaves, 2000; Zembylas, 2007). Liisa brings up how this particular teacher was not so popular among the students and also, that although she was interested in biology, she "never felt that I was any better than the others". Considering what Liisa said about not feeling any better than the others, it can be asked whether the teacher had succeeded in creating such a teaching and learning environment where all students were treated equally, hence avoiding a situation where some students would be "teacher's pets". After all, Liisa did not talk about her teacher's public display of the positive feedback in the classroom, but rather that the teacher arranged a personal meeting with Liisa of which this memory is telling about. While Liisa was expecting the worst, she was given a speech that made her feel special and believed in, which only reinforced her interest in studying biology and gave her the confidence that it was the right path for her. Again, the meaning of the event for the student at the school time and in the future is revealed by Liisa.

\subsection{A teacher provided students insights, experiences or meaningful events}




\section{TEACHER-STUDENT RELATIONSHIPS AND THE EMOTIONS INVOLVED}

There were memories, remembered in detail, in which teachers provided their students specific insights, experiences or meaningful events. The next memory describes this aspect in the teacher-student relationships and the emotions involved. Helena, a female writer in her late fifties, tells only about the following two elementary school teachers:

One more memory from the turn of the years 1960 and 1961. I had received an invitation from Erkki and Elina [the teacher couple ${ }^{7}$ who taught in the village school where Helena studied] to come to their home to celebrate New Year. I accepted the invitation blissfully, as it was really something, to visit a teacher ... I don't think I told anyone about this, as it would had invoked envy - the others would have called me a teacher's pet. Was I a teacher's pet? I don't know. Sometimes I have wondered how difficult it is to be fair. You can try to be fair, but you just like some people more than others. You just can't help it. The invitation was also pleasing because my own home was poor. Our mum was not always able to prepare for Christmas: the cleaning, the baking, not to mention the presents. Worries about everyday life absorbed her strength and enthusiasm, and there was a constant lack of money.

I wished I could see a real home, its people and atmosphere. I would get a memory that never disappears. I can't describe it in words ... There was the bustle of children in the early evening, some went to bed earlier. Maybe Jukka [the teachers' son] was allowed to stay up later - he was already in the second grade. There were Christmas decorations in the dining room: a Christmas tree, candles, tablecloths and pastries. There was - how can I describe it - a lovely brass candelabra on the table with four little angels who blew into a trombone, and four candles. When the candles were burning, the heat made the angels spin, and you could hear slight tinkling sound. It was so beautiful; I remember wishing I could get one.

As the turn of the year started to approach, the radio was on. The bells of Turku Cathedral started to peal, and the powerful hymn A Mighty Fortress is our God rang out. Erkki hugged his wife, apologised

\footnotetext{
${ }^{7}$ Historically, it was quite common in Finland, especially in small village schools, for a wife and husband to both work as teachers in the same school. Usually, the female teacher taught the lower grades, whereas the male teacher taught the upper grades and acted as the principal. The teachers usually also lived in a building close to or attached to the school building.
} 


\section{TEACHER-STUDENT RELATIONSHIPS AND THE EMOTIONS INVOLVED}

for his insufficiency and wished his wife Elina a blessing for the year 1962, and they both also hugged me with the same message. A warm tear rolled down my cheek ... I had got my own blessing. At the turn of every year since, I have relived this moment again and again and remembered those two in my prayers ... I was lucky to have them as my teachers, and I remember and bless them gratefully. (Email 18)

The above memory describes Helena's close and personal relationship with her teachers in and out-of-school context (Uitto, 2012; van Manen \& Li, 2002). The use of the teachers' first names illustrates the closeness and intimacy of this relationship. Again, emotions involved in teacherstudent relationships become described evolving in the midst of other relationships (see Hargreaves, 2000; Zembylas, 2007): Helena tells about her teachers' children, her own mother and other students as well. Yet, although Helena describes having felt special and different from the other students, she wondered whether she was indeed the teachers' favourite and reflected on the issue from the perspective of other students. Helena reveals that she lived in poor socio-economic circumstances, and the difficulty of such a life hindered and overshadowed celebrations such as the one described. However, as a child, she remembers her desire to experience "a real home, its people and atmosphere", which is what the invitation to teacher's home gave her. This event displayed the teacher's pedagogical tact towards the student and her background (van Manen, 1991). In all, this memory further demonstrates that a teacher's role can extend far beyond the school context: sometimes teachers can be considered family. On the other hand, one may ask whether the teachers acted here as model citizens who were trying to show the student what one is supposed to aim at (Tuomaala, 2004).

The meaning of visiting the teachers' home to celebrate New Year is emphasised in the memory. The emotions are explicitly present as Helena tells about her own bliss to visit teachers' home and not telling about the visit to other students to prevent them from feeling envy. She also describes her mother's emotions (worry). The memory has an overall emotional tone and the emotional significance of this event for Helena is captured in the vivid description and amount of 


\section{TEACHER-STUDENT RELATIONSHIPS AND THE EMOTIONS INVOLVED}

detail about the scenery and how she says that, "I have relived this moment again and again". This further reminds us about the meaning of teacher-student relationships extending over the school years. Emotions involved in the teacher-student relationships are further elaborated in the emotional bond between Helena and the teacher couple and in Helena's positive emotions and gratitude about having felt, at least for one evening, being a part of that family and in a "real" home.

\section{Discussion}

This article explores former students' positive memories of their teachers and asks what those memories tell us about teacher-student relationships and the emotions involved. Our findings illustrate the emphasis of the memories on the relationships rather than on the teachers' knowledge, the details of the subject matter or teachers' competences and abilities to teach or transmit knowledge. The memories not only go beyond different subjects, but also often stretch beyond the school context into informal occasions and encounters. The teachers are not described only as representatives of a particular subject, but rather as how they were as human beings and in relation to the meaning of their role as educators in a broader sense.

Our research raises up the student perspective on teacher-student relationships and the emotions involved, whereas prior research has mostly focused on teachers' perspectives (e.g. Hargreaves, 2000; Newberry, 2010; Yan et al., 2011). Emotions in teacher-student relationships are illustrated in several ways: the remembered teachers were described according to the deep emotional bonds that they established with students (Hargreaves, 1998; Nias, 1996; O'Connor, 2008), these teachers were described as sensitive towards the students' life circumstances and emotions, and they cared about the students' background, their talents or challenges. They were willing to help and were deeply empathetic, not limiting themselves to the school issues and even taking on different roles other than that of an educator, more akin to being a parent. In some cases, 


\section{TEACHER-STUDENT RELATIONSHIPS AND THE EMOTIONS INVOLVED}

this resulted in a life-long relationship with a teacher (Uitto, 2012). All these characteristics demonstrate teachers' profound socio-emotional involvement in their students' lives. To a great extent, students' memories are well aligned with the research into teachers' perspective on emotions in their work and their relationships with students (e.g. Hargreaves, 1998; O’Connor, 2008).

Our research supported the notion of the key role that emotions have in long-lasting memories as the participants of the research were not explicitly invited to write about their emotions, yet the emotions emerged in the memories. Building on Sadler (2013), arguably, the emotions in teacherstudent relationships appeared as "far reaching, not easily defined and contain a variety of different types of emotions" (p. 158). Our research speaks in favor of examining emotions more holistically via stories, as this approach counters the commonly measured positive-negative emotion dichotomy (Pekrun et al, 2014) and provides a perspective on emotions as embedded in social relationships and their diverse representations in stories. This diversity in how emotions appear in individual stories is, arguably, greatly influenced by narrators' ways of expression.

Whereas sometimes the memories recalled described longer periods of time, others were related to a very specific incident that happened only once. This illustrates how even the smallest moments count in how teachers are remembered via their emotionality towards their students' needs. This is similar to what van Manen (1991) says about pedagogical moments during which teachers make decisions and act quickly, and how vital from the viewpoint of pedagogical tact these moments in fact are. Elaborating on van Manen's (1991) discussion of pedagogical moments, we see that teachers' encounters with a particular student not only required them to act in a pedagogically tactful way, but also to be sensitive to the circumstances of their students and their emotions. Although the relationships with teachers described by former students in this research certainly were pedagogical, it was the element of emotions that added value to the relationship, making it educational but at the same time personal and individualised. 


\section{TEACHER-STUDENT RELATIONSHIPS AND THE EMOTIONS INVOLVED}

In our research material, teachers' socio-emotional involvement in students' lives was also reflected in students' emotions. For example, it was illustrated how the experiences with teachers became lasting memories due to their positive emotional connotations and how a particular teacherstudent relationship could become significant for the student not only during the school years but also later in life. However, the memories also revealed the emotional significance of a teacher's encouragement and feedback for a particular student, as well as the teacher's ability to create in her/his students the feeling of being special and believed in. These aspects seemed to provide the individuals in this research with confidence and motivation to engage in school, as well as for their future educational paths (see also Roorda, Koomen, Spilt, \& Oort, 2011). From the perspective of students' emotions, our findings thus suggest that it is the students' feeling of being important to a particular teacher that is life-changing, and that feeling seems to arise from teachers' work as being emotional by nature. Considering that prior research has often demonstrated students' negative experiences with teachers (e.g. DePalma et al., 2011), our findings contribute to a broader understanding of teachers as professionals and persons, their work and their central role in people's lives. In addition, we see that the memories presented here are able to expand the cultural stock of stories about teachers.

Our research illustrates the central role that emotions have in teachers' work and especially in teacher-student relationships (Hargreaves, 2001; Zembylas, 2003). Furthermore, it is illustrated how emotions in the relationships between teachers and students evolve among other relationships (Hargreaves, 2000; Zembylas, 2007). The findings highlight the significance of taking more seriously into account emotions in teacher-student relationships and, hence, promoting these aspects more profoundly in teacher education of future primary and secondary teachers. We build on Denzin (1984), who noted that, "The self of the person stands in the center of the emotions that are experienced. Self-feelings constitute the inner essence, or core of emotionality." (p. 6). From this viewpoint, the approach we labelled as 


\section{TEACHER-STUDENT RELATIONSHIPS AND THE EMOTIONS INVOLVED}

identity-based (Lutovac \& Kaasila, 2014; see also Korthagen, 2004), allows future teachers to be involved in great amount of reflective work upon their identities (Kaasila, Lutovac, \& Lauriala 2014; Lauriala, 2013), but also allows them to reflect upon the emotions in teachers' work. For example, future teachers would explore not only the significance their own teachers had in their lives and the role they will play in their students' lives, but it also allows them to explore emotions involved in teacher-student relationships. However, this does not mean neglecting the emphasis on acquiring adequate knowledge of the particular subject matter or pedagogical knowledge during teacher education. Rather, it means placing it in a more holistic setting where every pre-service teacher has the opportunity to develop as a professional and a person as well as acquire a willingness for self-development, all while keeping in mind teacher-student relationships and the need to act according to students' needs and assist their growth.

That future teachers can fully understand the significance of emotions in teacher-student relationships, supporting the social and emotional development of themselves is crucial. Pre-service teachers could be assisted in becoming aware of their students' emotions and be taught how to understand or interpret them. They could also be assisted in developing awareness of their own emotions. Moreover, future teachers would benefit from being taught not only take the students' perspective in relation to how students feel, but also in relation to how students think while learning

(Ng \& Anderson, 2011). This would establish a balance between the emotional and cognitive dimensions in teaching (Damasio, 1999). Arguably, an approach that takes into account student emotions is needed in teacher education and may provide an appropriate setting for this balance and thus promote the development of future teachers' work as emotional and relational by nature. Likewise, we see that teachers in general should be aware of the significant role they play in students' lives, for good or bad. 


\section{TEACHER-STUDENT RELATIONSHIPS AND THE EMOTIONS INVOLVED}

Our article emphasises the meaning of emotions in teachers' work, but we do acknowledge some barriers to emotionality. The kind of emotional involvement described in our research material may, for many teachers, become a source of stress at work (Johnson et al., 2005). In addition, strong emotional involvement, such as taking on the role of a "parent", may sometimes, as Gellert (2000) suggests, result in teaching being disconnected from what should actually be taught and learnt. This means that when a lot of investment is put into caring, teachers may be distracted from accomplishing other goals in teaching and learning processes. From the viewpoint of equality, one may also question the role of emotions. Memories of being a teacher's pet can be seen as only one form of storytelling, and ideally all students may be able to feel special or in some way meaningful to the teacher. However, this is certainly not always the case (Luttrell, 1993; Martin, 1984), and hence, it may be difficult for a teacher to find the line of treating all students equally, or so that all the students would feel that they are important and appreciated. On the other hand, whether a particular student was a teacher's pet or a class victim, we see both cases as a matter of emotions. Similarly, research on students' memories of negative school time experiences has demonstrated that these experiences often arise from teachers' insensitivity towards students (Lutovac \& Kaasila, 2011; 2014).

Finally, based on our findings, we suggest further research to teacher-student relationships and the emotions involved from the students' viewpoint, but also from the teachers'. This will allow an understanding of what matters the most to students as well as teachers and help educate future teachers in such a way that they can best respond to students' needs. In addition, the understanding that teachers' work is inevitably relational and emotional calls for more empirical research on how teachers need to engage in emotional relationships with individual students. This will help assist future teachers in their needs for teaching. 


\section{Acknowledgements}

This article is a part of the project titled "Disentangling the emotional dimension in beginning teachers' work (EMOT)" funded by the Academy of Finland [grant no. 265974].

\section{References}

Aultman, L. P., Williams-Johnson, M. R., \& Schutz, P. A. (2009). Boundary dilemmas in teacherstudent relationships: Struggling with "the line”. Teaching and Teacher Education, 25(5), 636646. doi:10.1016/j.tate.2008.10.002

Becker, E. S., Goetz, T., Morger, V., \& Ranellucci, J. (2014). The importance of teachers' emotions and instructional behavior for their students' emotions - an experience sampling analysis. Teaching and Teacher Education, 43, 15-26. doi: 10.1016/j.tate.2014.05.002

Boler, M. (1999). Feeling power. Emotions and education. New York, NY: Routledge.

Carter, K. (1993). The place of story in the study of teaching and teacher education. Educational Researcher, 22(1), 5-12 \& 18. https://doi.org/10.3102/0013189X022001005

Chan, D. W. (2009). The hierarchy of strengths: Their relationships with subjective well-being among Chinese teachers in Hong Kong. Teaching and Teacher Education, 25(6), 867-875. doi: 10.1016/j.tate.2009.01.010

Chang-Kredl, S., \& Colannino, D. (2017). Constructing the image of the teacher on Reddit: Best and worst memories. Teaching and Teacher Education, 64, 43-51. doi: 10.1016/j.tate.2017.01.019

Chang-Kredl, S., \& Kingsley, S. (2014). Identity expectations in early childhood teacher education: Pre-service teachers' memories of prior experiences and reasons for entry into the profession. Teaching and Teacher Education, 43, 27-36. doi: 10.1016/j.tate.2014.05.005 


\section{TEACHER-STUDENT RELATIONSHIPS AND THE EMOTIONS INVOLVED}

Corcoran, R. P., \& Tormey, R. (2012). How emotionally intelligent are pre-service teachers? Teaching and Teacher Education, 28(5), 750-759. doi:10.1016/j.tate.2012.02.007

Cowie, N. (2011). Emotions that experienced English as a foreign language (EFL) teachers feel about their students, their colleagues and their work. Teaching and Teacher Education, 27(1), 235-242. doi:10.1016/j.tate.2010.08.006

Crawford, J., Kippax, S., Onyx, J., Gault, U., \& Benton, P. (1992). Emotion and gender. Constructing meaning from memory. London: Sage Publications.

Damasio, A. R. (1999). The feeling of what happens: Body and emotion in the making of consciousness. Orlando, FL: Harcourt Brace.

Day, C., \& Leitch, R. (2001). Teachers' and teacher educators' lives: The role of emotion. Teaching and Teacher Education, 17(4), 403-415. doi:10.1016/S0742-051X(01)00003-8

Den Brok, P., van der Want, A., Beijaard, D., \& Wubbels, T. (2013). The interpersonal dimension in the classroom: A model of teachers' interpersonal role identity, appraisal and teacher-student relationships. In M. Newberry, A. Gallant, \& P. Riley (Eds.), Emotion and school: Understanding how the hidden curriculum influences relationships, leadership, teaching and learning (pp. 141-161). Bingley, UK: Emerald.

Denzin, N. (1984). On understanding emotion. San Francisco, CA: Jossey-Bass.

DePalma, R., Membiela, P., \& Suárez, Pazos M. (2011). Teachers' memories of disciplinary control strategies from their own school days. British Journal of Sociology of Education, 32(1), 75-91. doi:10.1080/01425692.2011.532585

Elbaz-Luwisch, F. (2005). Teachers'voices: Storytelling and possibility. Greenwich, CT: Information Age Publishing.

Flores, M. A., \& Day, C. (2006). Contexts which shape and reshape new teachers' identities: a multi-perspective study. Teaching and Teacher Education, 22(2), 219-232. doi:10.1016/j.tate.2005.09.002 


\section{TEACHER-STUDENT RELATIONSHIPS AND THE EMOTIONS INVOLVED}

Fried, L., Mansfield, C., \& Dobozy, E. (2015). Teacher emotion research: introducing a conceptual model to guide future research. Issues in Educational Research, 25(4), 415-441.

Gellert, U. W. E. (2000). Mathematics instruction in safe space: Prospective elementary teachers' views of mathematics education. Journal of Mathematics Teacher Education, 3, 251-270. doi:10.1023/A:1009965408053

Hansen, D.T. (1998). The moral is in the practice. Teaching and Teacher Education, 14(6), 643655. doi:10.1016/S0742-051X(98)00014-6

Hargreaves, A. (1998). The emotional practice of teaching. Teaching and Teacher Education, 14(8), 835-854. http://dx.doi.org/10.1016/S0742-051X(98)00025-0

Hargreaves, A. (2000). Mixed emotions: Teachers' perceptions of their interactions with students. Teaching and Teacher Education, 16(8), 811-826. doi:10.1016/S0742-051X(00)00028-7

Hargreaves, A. (2001). Emotional geographies of teaching. Teachers College Record, 103(6), 1056-1080. doi:10.1111/0161-4681.00142

Hargreaves, A. (2005). Educational change takes ages: Life, career and generational factors in teachers' emotional responses to educational change. Teaching and Teacher Education, 21(8), 967-983. doi:10.1016/j.tate.2005.06.007

Hosotani, R., \& Imai-Matsumura, K. (2011). Emotional experience, expression, and regulation of high-quality Japanese elementary school teachers. Teaching and Teacher Education, 27(6), 1039-1048. doi:10.1016/j.tate.2011.03.010

Howells, K. (2014). An exploration of the role of gratitude in enhancing teacher-student relationships. Teaching and Teacher Education, 42, 58-67. doi: 10.1016/j.tate.2014.04.004

Isenbarger, L., \& Zembylas, M. (2006). The emotional labour of caring in teaching. Teaching and Teacher Education, 22(1), 120-134. doi:10.1016/j.tate.2005.07.002 


\section{TEACHER-STUDENT RELATIONSHIPS AND THE EMOTIONS INVOLVED}

Johnson, S., Cooper, C., Cartwright, S., Donald, I., Taylor, P., \& Millet, C. (2005). The experience of work-related stress across occupations. Journal of Managerial Psychology, 20, 178-187. doi: $10.1108 / 02683940510579803$

Kaasila, R. (2007). Using narrative inquiry for investigating the becoming of a mathematics teacher. ZDM, 39(3), 205-213. doi: 10.1007/s11858-007-0023-6

Kaasila, R. Lutovac, S., \& Lauriala, A. (2014). The meaning of teaching practice in developing research-based teacher education in mathematics education context in Finland. In J. Calvo de Mora, \& K. Wood (Eds.), Practical knowledge in teacher education-Approaches to teacher internship programs (pp. 31-43). London: Routledge.

Kelchtermans, G. (2005). Teachers' emotions in educational reforms: Self-understanding, vulnerable commitment and micropolitical literacy. Teaching and Teacher Education, 21(8), 995-1006. doi:10.1016/j.tate.2005.06.009

Kelchtermans, G. (2009). Who I am in how I teach is the message: self-understanding, vulnerability and reflection. Teachers and Teaching: Theory and Practice, 15(2), 257-272. doi:10.1080/13540600902875332

Korthagen, F. A. J. (2004). In search of the essence of a good teacher: Towards a more holistic approach in teacher education. Teaching and Teacher Education, 20, 77-97. doi:10.1016/j.tate.2003.10.002

Lasky, S. (2000). The cultural and emotional politics of teacher-parent interactions. Teaching and Teacher Education, 16(8), 843-860. doi: 10.1016/S0742-051X(00)00030-5

Lauriala, A. (2013). Changes in research paradigms and their impact on teachers and teacher education: A Finnish case. In C. J. Craig, P. C. Meijer, \& J. Broeckmans (Eds.), From teacher thinking to teachers and teaching: The evolution of a research community, Advances in Research on Teaching: Vol. 19 (pp. 569-595). Bingley: Emerald Group Publishing Limited. 


\section{TEACHER-STUDENT RELATIONSHIPS AND THE EMOTIONS INVOLVED}

Lieblich, A., Tuval-Mashiach, R., \& Zilber, T. (1998). Narrative research: Reading, analysis and interpretation. London: Sage.

Lutovac, S., \& Kaasila, R. (2011). Beginning a pre-service teacher's mathematical identity work through narrative rehabilitation and bibliotherapy. Teaching in Higher Education, 16(2), 225236. doi: 10.1080/13562517.2010.515025

Lutovac, S., \& Kaasila, R. (2014). Pre-service teachers' future-oriented mathematical identity work. Educational Studies in Mathematics, 85(1), 129-142. doi: 10.1007/s10649-013-9500-8

Luttrell, W. (1993). "The teachers, they all had their pets": Concepts of gender, knowledge, and power. Signs: Journal of Women in Culture and Society, 18(3), 505-546. doi:10.1086/494818

Martin, W. B. W. (1984). Student perception of teachers' pets and class victims. Canadian Journal of Education, 9(1), 89-99.

Mayer, D. K. (2009). Entering the emotional practices of teaching. In P. A. Schutz, \& M. Zembylas (Eds.), Advances in teacher emotion research (pp. 73-91). Dordrecht: Springer.

Mitchell, C., \& Weber, S. (1999). Reinventing ourselves as teachers: Beyond nostalgia. London: Falmer Press.

Morcom, V. (2014). Scaffolding social and emotional learning in an elementary classroom community: A sociocultural perspective. International Journal of Educational Research, 67, 18-29. doi:10.1016/j.ijer.2014.04.002

Newberry, M. (2010). Identified phases in the building and maintaining of positive teacher-student relationships. Teaching and Teacher Education, 26(8), 1695-1703. doi:10.1016/j.tate.2010.06.022

Newberry, M., \& Davis, H. A. (2008). The role of elementary teachers' conceptions of closeness to students on their differential behaviour in the classroom. Teaching and Teacher Education, 24(8), 1965-1985. doi:10.1016/j.tate.2008.02.015 


\section{TEACHER-STUDENT RELATIONSHIPS AND THE EMOTIONS INVOLVED}

Ng, D., \& Anderson, K. (2011) Cognitive empathy and mathematics teaching. In B. Ubuz (Ed.), Proceedings of the 35th conference of the International Group for the Psychology of Mathematics Education: Developing mathematical thinking (Vol. 3, pp. 273-280). Ankara: PME.

Nias, J. (1996). Thinking about feeling: The emotions in teaching. Cambridge Journal of Education 26(3), 293-306. doi:10.1080/0305764960260301

O’Connor, K. E. (2008). "You choose to care": Teachers, emotions and professional identity. Teaching and Teacher Education, 24(1), 117-126. doi:10.1016/j.tate.2006.11.008

Paul, J. L., \& Smith, T. J. (Eds.) (2000). Stories out of school. Memories and reflections on care and cruelty in the classroom. Stamford, CT: Ablex Publishing Corporation.

Pekrun, R., Cusack, A., Murayama, K., Elliot, A. J., \& Thomas, K. (2014). The power of anticipated feedback: effects on students' achievement goals and achievement emotions. Learning and Instruction, 29,115-124. doi: 10.1016/j.learninstruc.2013.09.002

Raufelder, D., Nitsche, L., Breitmeyer, S., Keßler, S., Herrmann, E., \& Regner, N. (2016). Students' perception of "good" and "bad" teachers—-Results of a qualitative thematic analysis with German adolescents. International Journal of Educational Research 75, 31-44. doi: 10.1016/j.ljer.2015.11004

Riessman, C. K. (2008). Narrative methods for the human sciences. Los Angeles, CA: Sage Publications.

Roorda, D. L., Koomen, H. M., Spilt, J. L., \& Oort, F. J. (2011). The influence of affective teacherstudent relationships on students' school engagement and achievement: a meta-analytic approach. Review of Educational Research, 81(4), 493-529. doi: 10.3102/0034654311421793

Sadler, I. (2013). The role of self-confidence in learning to teach in higher education. Innovations in Education and Teaching International, 50(2), 157-166. doi: 10.1080/14703297.2012.760777 


\section{TEACHER-STUDENT RELATIONSHIPS AND THE EMOTIONS INVOLVED}

Salo, U.-M. (2005). Ankarat silkkaa hyvyyttään. Suomalainen opettajuus [Strict out of sheer goodness. Finnish teacherhood]. Porvoo: WSOY.

Schutz, P. A., \& Zembylas, M. (2009). Introduction to advances in teacher emotion research: the impact on teachers' lives. In P. A. Schutz, \& M. Zembylas (Eds.), Advances in teacher emotion research: The impact on teachers' lives (pp. 3-11). Dordrecht: Springer.

Shapiro, S. (2010). Revisiting the teachers' lounge: Reflections on emotional experience and teacher identity. Teaching and Teacher Education, 26(3), 616-621. doi: 10.1016/j.tate.2009.0

Simola, H., Heikkinen, S., \& Silvonen, J. (1998). A catalog of possibilities: Foucaultian history of truth and education research. In T.S. Popkewitz, \& M. Brennan (Eds.), Foucault's challenge. Discourse, knowledge, and power in education (pp. 64-90). New York: Teachers College Press.

Skaalvik, E. M., \& Skaalvik, S. (2009). Does school context matter? Relations with teacher burnout and job satisfaction. Teaching and Teacher Education, 25(3), 518-524. doi: 10.1016/j.tate.2008.12.006

Soini, T., Pyhältö, K., \& Pietarinen, J. (2010). Pedagogical well-being: reflecting learning and wellbeing in teachers' work. Teachers and Teaching: Theory and Practice, 16(6), 735-751. doi: $10.1080 / 13540602.2010 .517690$

Southgate, E. (2003). Remembering school. Mapping continuities in power, subjectivity, \& emotion in stories of school life. New York, NY: Peter Lang.

Tuomaala, S. (2004). Työtätekevistä käsistä puhtaiksi ja kirjoittaviksi. Suomalaisen oppivelvollisuuskoulun ja maalaislasten kohtaaminen 1921-1939 [From working hands to clean and writing hands. Encounters between Finnish compulsory education and rural children, 19211939]. Helsinki: Suomalaisen Kirjallisuuden Seura. 


\section{TEACHER-STUDENT RELATIONSHIPS AND THE EMOTIONS INVOLVED}

Uitto, M. (2012). 'Behind every profession is a person': Students' written memories of their own teacher-student relationships. Teaching and Teacher Education, 28(2), 293-301. doi:10.1016/j.tate.2011.10.009

Uitto, M. (2011). Humiliation, unfairness and laughter: students recall power relations with teachers. Pedagogy, Culture \& Society, 19(2), 273-290. doi:10.1080/14681366.2011.582262

Uitto, M., \& Estola, E. (2009). Gender and emotions in relationships: Teachers recalling their own teachers. Gender and Education, 21(5), 517-530. doi:10.1080/09540250802667591

Uitto, M., Jokikokko, K., \& Estola, E. (2015). Virtual special issue on teachers and emotions in Teaching and Teacher Education in 1985-2014. Teaching and Teacher Education 50, 124-135. doi:10.1016/j.tate.2015.05.008

Van Manen, M. (1991). The tact of teaching. The meaning of pedagogical thoughtfulness. London, ON: Althouse Press.

Van Manen, M. (1994). Pedagogy, virtue, and narrative identity in teaching. Curriculum Inquiry, $4(2), 135-170$.

Van Manen, M. (2002). The tone of teaching. Ontario: The Althouse Press.

Van Manen, M., \& Li, S. (2002). The pathic principle of pedagogical language. Teaching and Teacher Education, 18(2), 215-224.

Yan, E. M., Evans, I. M., \& Harvey, S. T. (2011). Observing emotional interactions between teachers and students in elementary school classrooms. Journal of Research in Childhood Education, 25(1), 82-97. doi:10.1080/02568543.2011.533115

Zembylas, M. (2003). Emotions and teacher identity: A post-structural perspective. Teachers and Teaching: Theory and Practice, 9(3), 213-238. doi: 10.1080/13540600309378

Zembylas, M. (2004). The emotional characteristics of teaching: An ethnographic study of one teacher. Teaching and Teacher Education, 20(2), 185-201. doi: 10.1016/j.tate.2003.09.008 
TEACHER-STUDENT RELATIONSHIPS AND THE EMOTIONS INVOLVED

Zembylas, M. (2007). Theory and methodology in researching emotions in education. International Journal of Research \& Method in Education, 30(1), 57-72. doi:10/1080/17437270701207785 